\title{
Correction to: The role of ppary and autophagy in ros production, lipid droplets biogenesis and its involvement with colorectal cancer cells modulation
}

\author{
José Antonio Fagundes Assumpção, Kelly Grace Magalhães and José Raimundo Corrêa* (1)
}

\section{Correction to: Cancer Cell Int (2017) 17:82 DOI 10.1186/s12935-017-0451-5}

Upon publication of the original article [1], it was noticed that corresponding author status has been erroneously attributed to José Antonio Fagundes Assumpção. The corresponding author of this manuscript should be noted as José Raimundo Corrêa (correa@unb.br).

This error has since been acknowledged and corrected in this Correction.

The online version of the original article can be found under doi:10.1186/s12935-017-0451-5.

\section{Publisher's Note}

Springer Nature remains neutral with regard to jurisdictional claims in published maps and institutional affiliations.

Received: 17 October 2017 Accepted: 17 October 2017

Published online: 02 November 2017

\section{Reference}

1. Assumpção JAF, Magalhães KG, Corrêa JR. The role of ppary and autophagy in ros production, lipid droplets biogenesis and its involvement with colorectal cancer cells modulation. Cancer Cell Int. 2017;17(1):82. doi:10.1186/s12935-017-0451-5. 